Original Research Paper

\title{
Struktur Komunitas Moluska di Kawasan Mangrove Alami dan Rehabilitasi Pesisir Selatan Pulau Lombok
}

\author{
Dining Aidil Candri ${ }^{1}$, Laily Hunawatun Sani ${ }^{*}$, Hilman Ahyadi ${ }^{1}$, Baiq Farista ${ }^{1}$ \\ ${ }^{1}$ Program Studi Biologi, Fakultas Matematika dan Ilmu Pengetahuan Alam, Universitas Mataram, Mataram, Indonesia
}

\author{
Riwayat artikel \\ Received : 09 Oktober 2019 \\ Revised : 05 April 2020 \\ Accepted : 11 April 2020 \\ Published : 23 April 2020 \\ *Corresponding Author: \\ Laily Hunawatun Sani, \\ Program Studi Biologi, \\ Fakultas Matematika dan Ilmu \\ Pengetahuan Alam, Universitas \\ Mataram, Indonesia \\ Email: \\ el.tsanni179@gmail.com
}

\begin{abstract}
Abstrak: Struktur komunitas moluska di suatu ekosistem mangrove dapat digunakan sebagai indikator status kesehatan ekosistem tersebut. Dalam penelitian ini dilakukan pembandingan antara struktur komunitas moluska di ekosistem mangrove alami dan rehabilitasi untuk melihat adanya perbedaan struktur moluska di kedua kondisi ekosistem tersebut. Penelitian ini telah dilakukan pada bulan Maret - Juni 2019 pada 2 tipe ekosistem mangrove yaitu ekosistem mangrove alami di Pemongkong, Lombok Timur dan ekosistem mangrove rehabilitasi di teluk Gerupuk, Lombok Tengah. Pengambilan data dilakukan dengan metode purposive random sampling dengan meletakkan 3 plot berukuran 1x1 m secara acak di dalam plot yang berukuran lebih besar $(10 \times 10 \mathrm{~m})$ yang telah ditentukan sebelumnya. Adapun hasil penelitian menunjukkan terdapat 37 spesies moluska yang termasuk ke dalam 14 famili. 14 spesies ditemukan di kedua lokasi penelitian, 3 spesies hanya ditemukan di kawasan rehabilitasi, dan 20 spesies lainnya hanya ditemukan di kawasan mangrove alami Pemongkong. Ekosistem mangrove alami Pemongkong memiliki kemelimpahan moluska lebih tinggi yakni mencapai $77.692 \mathrm{ind} / \mathrm{m}^{2}$, dibandingkan dengan ekosistem mangrove rehabilitasi yang hanya mencapai $48.746 \mathrm{ind} / \mathrm{m} 2$. Famili Potamididae memiliki keanekaragaman dan kemelimpahan tertinggi di kedua lokasi penelitian. Berdasarkan proporsi setiap spesies dalam komunitas moluska yang ditemukan, persamaan kedua lokasi penelitian yang ditunjukkan dengan Persent similaritas (PS) tergolong rendah yakni hanya mencapai kemiripan 36,36\% .Keanekaragaman vegetasi mangrove, usia vegetasi, serta kondisi lingkungan dapat menjadi faktor yang mendukung perbedaan struktur komunitas moluska tersebut.
\end{abstract}

Kata kunci: Struktur komunits, Moluska, Mangrove, Alami, Rehabilitasi

Abstract: Mollusks community structure in a mangrove swamp can be used to describe the status of mangrove ecosystem's health. In this research, the mollusks community ini natural and rehabilitation mangrove ecosystem were compared in order to find the difference between these ecosystems. This research held on March to June 2019 at 2 types of mangrove ecosystem such as natural ecosystem at Pemongkong, East Lombok and rehabilitation ecosystem at Gerupuk bay. Data collection method used purposive random sampling by placed 3 plots sized $1 \times 1 \mathrm{~m}$ randomly in a larger plot $(10 \times 10 \mathrm{~m})$ which have been determine before. The result showed that there are 37 species of association of mollusks which belong to 14 families. 14 species found in both locations, 3 species only found at rehabilitation ecosystem, and 20 species left only found at natural mangrove ecosystem at Pemongkong. Natural mangrove ecosystem Pemongkong had higher abundance of association mollusks with number of abundance $77.692 \mathrm{ind} / \mathrm{m} 2$ against rehabilitation ecosystem which only reached $48.746 \mathrm{ind} / \mathrm{m} 2$. Potamididae has the highest diversity and abundance value in both location. The resemblance of these 2 ecosystem based on the proportion of each species in the mollusks community showed by Similarity Presentation categorized as low level which only reach $36,36 \%$ of similarity. Mangrove diversity, it's age, and the environmental condition may caused the difference in those mollusks structure community.

Key words: Structur community, Mollusks, Mangrove, Natural, Rehabilitation 


\section{Pendahuluan}

Ekosistem mangrove merupakan ekosistem khas daerah peisisir yang memiliki multifungsi yaitu fisik, ekologis, dan sosial ekonomi (Indriyanto, 2006; Sulastini, 2011). Ekosistem mangrove disebut sebagai kawasan produktif karena kaya akan bahan organik yang merupakan sumber makanan bagi biota, menjadi tempat berlindung dan memijah berbagai jenis biota seperti moluska dan biota-biota lain yang bernilai ekonomis tinggi seperti ikan dan udang (Bosire et al, 2005; Bowen et al, 2001; Bengen, 2000 dalam Waas dan Nababan, 2010).

Kerusakan hutan mangrove merupakan masalah serius yang kini sedang terjadi dan hampir terjadi di seluruh Indonesia, termasuk di pulau Lombok. Mujiono (2016) memenyatakan kawasan hutan mangrove Pulau Lombok yang masih dalam kondisi baik hanya sekitar 1.643 ha atau sekitar 49,7\% dari total 3.305 ha kawasan hutan mangrove Pulau Lombok. Sebagai upaya mengurangi laju kerusakan hutan mangrove, maka dilakukanlah rehabilitasi ekosistem mangrove.

Permasalahan muncul dari sistem rehabilitasi yang telah dilakukan. Sejauh ini, rehabilitasi ekosistem mangrove yang telah banyak dilakukan umumnya hanya menggunakan satu jenis tumbuhan mangrove yaitu dari genus Rhizopora, seperti yang dilakukan di Teluk Gerupuk, Lombok Tengah (Anwar dan Mertha, 2017; Ahyadi dan Suana, 2018) tanpa memperhatikan kondisi lokasi rehabilitasi dan zonasi ekosistem mangrove. Zonasi tumbuhan mangrove ini sangat mempengaruhi peranan mangrove baik peranan fisik maupun peranan secara ekologis, salah satunya terhadap jenis dan sebaran biota asosiasi, seperti Moluska.

Moluska merupakan salah satu kelompok makrozoobentos yang memiliki tubuh lunak dan sebagian besar mensekresikan kalsium karbonat yang membentuk cangkang keras dari zat kitin yang berfungsi dalam perlindungan diri (Simon et al, 2013; Starr et al, 2015). Kelompok ini berperan sebagai dekomposer serasah dan mineralisasi materi organik (Suzuki etal., 2002; Fratini et al., 2004; Hickman et al, 2008). Tekanan dan perubahan lingkungan cenderung mengakibatkan terjadinya perubahan pada ekosistem mangrove yang selanjutnya berpengaruh terhadap perubahan kondisi fisika, kimia, dan biologi hutan mangrove (Pribadi et al, 2009; Mujiono, 2016), termasuk keanekaragaman jenis serta kemelimpahan moluska asosiasi mangrove.

Saat ini belum didapatkan data yang menunjukkan bahwa sistem rehabilitasi yang telah dilakukan dengan menggunakan Rhizophora tidak mempengaruhi ekosistem secara umum terutama keberadaan moluska asosiasi tumbuhan mangrove. Hal tersebut dapat dibuktikan dengan membandingkan struktur komunitas moluska di ekosistem mangrove yang telah di rehabilitasi dengan Rhizophora dengan ekosistem yang masih alami. Adapun hasil yang penelitian nantinya dapat digunakan sebagai salah satu pertimbangan dalam melakukan rehabilitasi ekosistem mangrove kembali.

Di pulau Lombok, kawasan yang masih memiliki kedua tipe ekosistem mangrove tersebut adalah daerah pesisir selatan. Ekosistem mangrove alami dapat ditemukan di Desa Pemongkong, Lombok Timur, sedangkan kawasan rehabilitasi mangrove dengan jenis Rhizophora salah satunya adalah kawasan hutan mangrove Gerupuk, Lombok Tengah. Oleh karena itu, pendataan mengenai keanekaragaman biota asosiasi mangrove beserta kemelimpahannya di kawasan hutan mangrove rehabilitasi dan alami perlu dilakukan sehingga didapatkan cara yang tepat untuk memperbaiki ekosistem mangrove yang rusak ke depannya.

\section{Bahan dan Metode}

\section{a. Waktu dan Tempat Penelitian}

Penelitian ini dilaksanakan pada bulan Maret-Juni 2019 di dua lokasi hutan mangrove di pesisir selatan pulau Lombok yaitu hutan mangrove Gerupuk untuk mendapatkan data struktur komunitas moluska di kawasan rehabilitasi dan di hutan mangrove Desa Pemongkong, Kecamatan Jerowaru untuk mendapatkan data struktur komunitas moluska di kawasan mangrove alami.

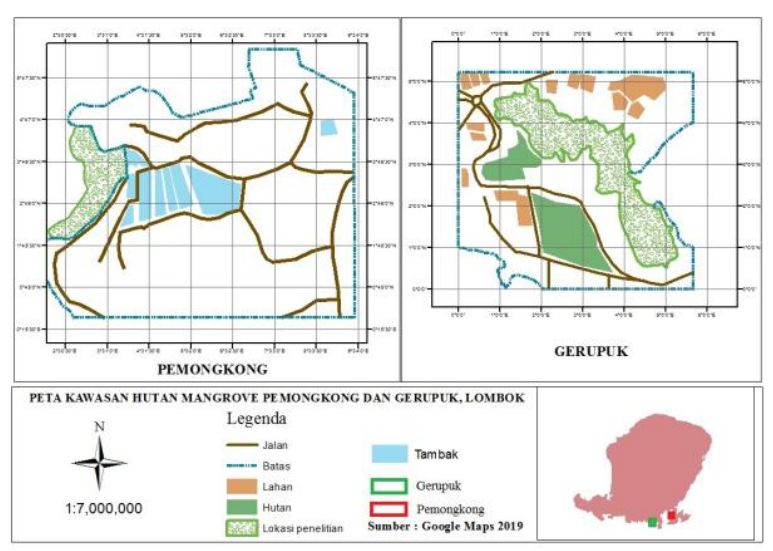

Gambar 1. Peta lokasi penelitian 


\section{b. Pengambilan data}

Pengambilan data dilakukan dengan metode purposive random sampling yaitu dengan menarik garis transek sepanjang kawasan penelitian dengan jarak antar transek sekitar $200 \mathrm{~m}$. Kemudian dalam masing-masing transek diletakkan secara berseling plot pengamatan berukuran 10 x $10 \mathrm{~m}$. Jarak antar plot sekitar $25 \mathrm{~m}$. Data moluska didapatkan dengan meletakkan 3 plot lain berukuran $1 \times 1 \mathrm{~m}$ secara acak dalam 10 x $10 \mathrm{~m}$ yang telah dibuat sebelumnya (Fitriana, 2006; Ernanto et al, 2010). Beberapa data yang diambil antara lain jenis dan jumlah individu moluska asosiasi yang ditemukan serta data fisik dan kimia lingkungan yang meliputi jenis dan kedalaman substrat, temperature udara dan substrat, salinitas perairan, dan kelembaban udara. Identifikasi jenis moluska dilakukan dengan menggunakan pustaka Abbott (1991) serta Abbot dan Dance (1998).

\section{c. Analisis data}

Analisis data yang dilakukan antara lain penentuan indeks keanekaragaman ( $\left.\mathrm{H}^{\prime}\right)$, indeks dominansi (C), dan kemelimpahan masing-masing spesies moluska asosiasi serta indeks similiaritas (ISS) dan presentase similiaritas (PS) untuk menentukan tingkat persamaan kedua lokasi penelitian (Smith and Smith, 2012; Molles Jr. and Sher, 2019; Aji dan Widyastuti, 2017).

\section{Hasil dan Pembahasan}

\section{a. Komposisi Moluska Mangrove}

Penelitian ini mengidentifikasi 37 spesies yang termasuk ke dalam 14 famili moluska asosiasi mangrove di ekosistem mangrove alami desa pemongkong dan ekosistem mangrove rehabilitasi Gerupuk, ditemukan (tabel 1). Sebanyak 14 spesies ditemukan di kedua lokasi penelitian, 3 spesies hanya ditemukan di ekosistem mangrove rehabilitasi Gerupuk dan 20 spesies lainnya hanya terdapat di ekosistem mangrove alami Pemongkong.

Studi mengenai komposisi spesies gastropoda di hutan mangrove telah beberapa kali dilakukan. Pribadi et al (2009) menemukan 29 spesies gastropoda mangrove di Segara Anakan, Cilacap. Jumlah spesies lebih banyak ditemukan oleh Mujiono (2016) di 6 stasiun pengamatan yang tersebar di Lombok Tengah dan Lombok Timur yaitu 31 spesies gastropoda asosiasi. Sebanyak 18 spesies yang ditemukan dalam penelitian ini dijumpai juga oleh Mujiono (2016). Hasil tersebut mungkin terjadi karena lokasi stasiun penelitian Mujiono (2016) masih berada di kawasan Lombok Tengah dan Lombok Timur yang juga merupakan lokasi penelitian ini.

Tabel 1. Kemelimpahan moluska asosiasi mangrove (ind $\left./ \mathrm{m}^{2}\right)$ di lokasi penelitian.

\begin{tabular}{|c|c|c|c|c|}
\hline \multirow{2}{*}{ No } & \multirow{2}{*}{ Famili } & \multirow{2}{*}{ Jenis Moluska } & \multicolumn{2}{|c|}{ Kelimpahan (ind $\left./ m^{2}\right)$} \\
\hline & & & Mangrove Gerupuk & Mangrove Pemongkong \\
\hline 1. & Assiminidae & Assiminea lutea $^{*}$ & 11.476 & 4.846 \\
\hline \multirow[t]{3}{*}{2.} & \multirow[t]{3}{*}{ Cerithiidae } & Clypeomorus pellucidus & - & 1.718 \\
\hline & & Clypeomorus bifasciatus & - & 1.641 \\
\hline & & Clypeomorus nympha & - & 0.307 \\
\hline \multirow[t]{5}{*}{3.} & \multirow[t]{5}{*}{ Ellobidae } & Cassidula nucleus ${ }^{*}$ & 0.460 & - \\
\hline & & Cassidula aurifelis $^{*}$ & 0.619 & - \\
\hline & & Cassidula vespertilionis ${ }^{*}$ & - & 0.769 \\
\hline & & Melampus sp. & - & 1.205 \\
\hline & & Melampus bidentatus & - & 0.436 \\
\hline 4. & Haminoeidae & Haminoea tenera $^{*}$ & 0.190 & 0.051 \\
\hline \multirow[t]{3}{*}{5.} & \multirow[t]{3}{*}{ Littorinidae } & Littorina scabra* & 0.047 & 6.256 \\
\hline & & Littorina carinifera ${ }^{*}$ & - & 4.435 \\
\hline & & Littorina lutea & - & 0.158 \\
\hline \multirow[t]{2}{*}{6.} & \multirow[t]{2}{*}{ Muricidae } & Chicoreus capunicus $^{*}$ & 3.793 & 1.154 \\
\hline & & Morula granulata & - & 3.641 \\
\hline \multirow[t]{3}{*}{7.} & \multirow[t]{3}{*}{ Neritidae } & Nerita polita & - & 0.538 \\
\hline & & Nerita undata* & - & 3.846 \\
\hline & & Nerita planospira* & - & 5 \\
\hline
\end{tabular}


Laily Hunawatun Sani et al., Jurnal Biologi Tropis, 20 (1): 139 - 147 DOI: 10.29303/ibt.v20i1.1385

\begin{tabular}{|c|c|c|c|c|}
\hline 8. & Onchidiidae & Platevindex sp. ${ }^{*}$ & 0.333 & 0.205 \\
\hline \multirow[t]{11}{*}{9.} & \multirow[t]{11}{*}{ Potamididae } & Cerithidea cingulata $^{*}$ & 13.539 & 10.667 \\
\hline & & Cerithidea quoyii ${ }^{*}$ & 3.873 & 4.641 \\
\hline & & Cerithidea obtuse & 2 & 4.307 \\
\hline & & Cerithidea quadrata & 1 & 1.359 \\
\hline & & Cerithideopsila alata $^{*}$ & - & 2.307 \\
\hline & & Terebralia palustris ${ }^{*}$ & - & 3.538 \\
\hline & & Terebralia sulcata* $^{*}$ & 5.603 & 1.025 \\
\hline & & Terebralia spp. 1 & 2.873 & 0.846 \\
\hline & & Terebralia spp. 2 & 2.650 & 0.358 \\
\hline & & Batillaria zonalis & - & 7.179 \\
\hline & & Telescopium telescopium* $^{*}$ & 0.285 & - \\
\hline 10. & Palanaxidae & Palanaxis sulcatus & - & 1.846 \\
\hline 11. & Trochidae & Monodonta labio $^{*}$ & - & 0.769 \\
\hline \multirow[t]{2}{*}{12.} & \multirow[t]{2}{*}{ Thiaridae } & Melanoides sp. & - & 0.846 \\
\hline & & Melanoides tuberculata ${ }^{*}$ & - & 0.179 \\
\hline 13. & Isognomonidae & Isognomon alatus & - & 2.154 \\
\hline \multirow[t]{3}{*}{14.} & Arcidae & Anadara granosa & - & 0.487 \\
\hline & & Anadara maculosa & - & 0.077 \\
\hline & & Kelimpahan total & 48.746 & 77.692 \\
\hline
\end{tabular}

Keterangan: (-) : tidak ditemukan di lokasi penelitian; (*) spesies yang ditemukan oleh Mujiono (2016).

Secara keseluruhan, kelimpahan moluska di Pemongkong lebih tinggi dibandingkan Gerupuk, dengan nilai berturut-turut 77.692 ind $m^{2}$ dan 48.746 ind $/ m^{2}$. Cerithidea cingulata memiliki kemelimpahan tertinggi di kedua lokasi penelitian, dengan tingkat kemelimpahan di mangrove Gerupuk sebesar 13.539 ind $/ m^{2}$ dan di mangrove Pemongkong sebesar 10.667 ind/ $m^{2}$. C. cingulata termasuk ke dalam famili Potamididae yang merupakan famili dengan spesies terbanyak ditemukan dalam penelitian ini. Terdapat 10 spesies famili Potamididae yang ditemukan, 7 spesies ditemukan di kedua lokasi penelitian yaitu $C$. cingulata, C. quoyii, C. obtuse, Cerithideopsilla alata, Terebralia sulcata, Terebralia spp. dan Terebralia spp.2, sedangkan 1 spesies yaitu Telescopium telescopium hanya ditemukan di ekosistem mangrove rehabilitasi Gerupuk, dan 2 spesies lainnya yaitu Terebralia palustris dan Batillaria zonalis hanya terdapat di ekosistem mangrove alami Pemongkong. Famili Potamididae merupakan kelompok moluska mangrove yang paling sering ditemukan di kawasan ekosistem mangrove (Tuheteru et al, 2014; Nurrudin et al, 2015; Zvonareva et al, 2015; Baharuddin et al, 2017; Abubakar et al, 2018) karena kelompok ini termasuk moluska asli kawasan mangrove yang menyukai permukaan berlumpur seperti kondisi di kawasan penelitian ini (tabel 3) (Budiman, 2009; Supriharyono; 2009; Tuheteru et al, 2014; Goltenboth et al, 2012).

Selain $C$. cingulata dan anggota famili Potamididae lainnya, spesies yang memiliki kemelimpahan cukup tinggi adalah Assiminea lutea
(Assimineidae) dan Chicorius capunicus (Muricidae). Keduanya termasuk kelompok moluska asli mangrove yang persebarannya meliputi kawasan belakang hutan mangrove (Abbott dan Dance, 1991; Budiman, 2009; Goltenboth et al, 2012).Selain itu, kemelimpahan $C$. capunicus yang merupakan moluska karnivora yang bersifat oportunis cendrung disebabkan karena kemelimpahan jenis moluska lain termasuk Cerithidea spp. sebagai sumber makanannya di lokasi penelitian (Phintrakoon et al., dalam Mujiono, 2016). Baharuddin et al (2018) juga melaporkan bahwa gastropoda predator seperti Muricidae dapat ditemukan di seluruh zona dengan kemelimpahan moluska tinggi.

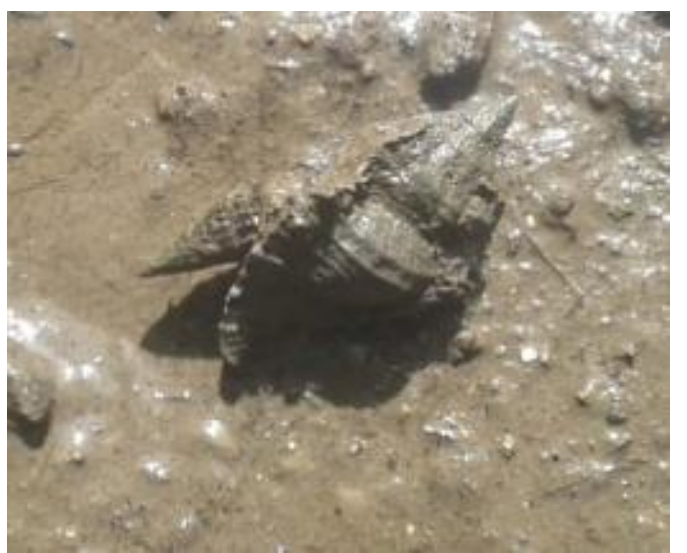

Gambar 2.C. capunicus sedang memakan Cerithidea sp. di ekosistem mangrove Gerupuk 
Faktor yang dapat menyebabkan kelimpahan moluska di Pemongkong lebih tinggi dibandingkan dengan Gerupuk antara lain; keanekaragaman jenis mangrove, usia vegetasi, serta faktor lingkungannya. Keanekaragaman jenis mangrove yang tinggi memberikan lebih banyak pilihan makanan bagi moluska. Supriharyono (2009) menyatakan bahwa makanan moluska cukup spesifik sehingga moluska pemakan daun Avicennia tidak dapat hidup jika Avicennia digantikan dengan mangrove jenis Rhizophora. Faktor tersebut menyebabkan beberapa spesies moluska seperti Littorinidae yang merupakan pemakan daun dan mikroepifit pada Avicennia spp. sangat sedikit atau bahkan tidak ditemukan di ekosistem mangrove rehabilitasi Gerupuk yang hanya ditanami oleh jenis Rhizophora.

Usia vegetasi mengacu pada stabilitas dari suatu ekosistem (Smith dan Smith, 2012; Molles dan Sher,

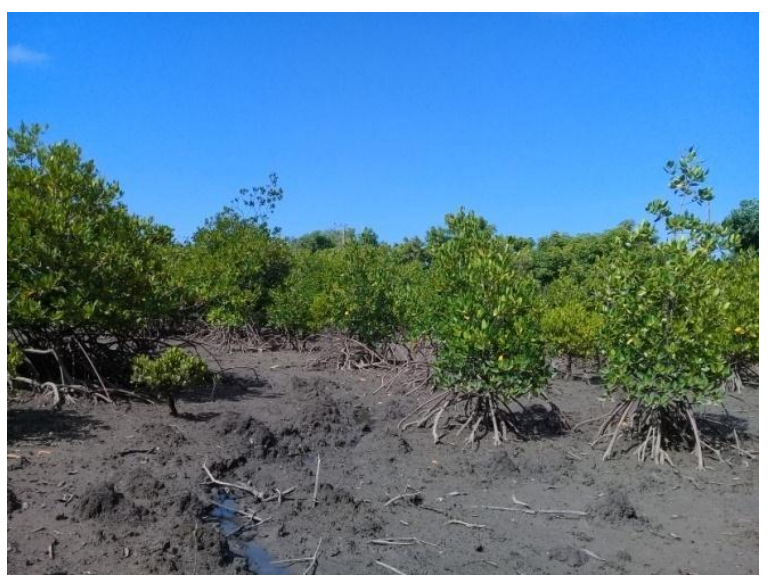

Gambar 3. Ekosistem mangrove rehabilitasi Teluk Gerupuk, Lombok Tengah

Keanekaragaman jenis (H') moluska asosiasi mangrove berbanding lurus dengan keanekaragaman jenis tumbuhan mangrove yang ditemukan. Tumbuhan mangrove berperan sebagai sumber makanan bagi berbagai jenis moluska asosiasi di sekitarnya, atau berperan pula sebagai tempat bernaung, menempelkan diri, ataupun tempat mencari makanan (Supriharyono, 2009; Harahab, 2010; Kordi, 2014). Jenis-jenis tumbuhan mangrove yang ditemukan di ekosistem mangrove alami Pemongkong antara lain Avicennia alba, A. marina, $C$. decandra, Rhizophora mucronata, Scyphiphora hydrophyllacea, Sonneratia alba, dan S. caseolaris. Moluska asosiasi terutama dari famili Littorinidae dan Neritidae ditemukan paling banyak menenpel pada akar, batang, atau daun Avicennia spp. Selain jenis A. alba, A. marina, dan $S$. hydrophyllacea, semua jenis mangrove tersebut ditemukan pula di ekosistem mangrove alami Gerupuk.
2019). Usia vegetasi mangrove Pemongkong diperkirakan sudah cukup tua dilihat dari diameter pohon $S$. alba yang ditemukan mencapai $50 \mathrm{~cm}$. Menurut Nazim et al (2013) tumbuhan mangrove dengan ukuran dbh sekitar $18-32$ $\mathrm{cm}$ memiliki usia sekitar 18-32 tahun dengan kecepatan tumbuh $1.15 \pm 0.17 \mathrm{~cm} /$ tahun (Aryanto et al, 2018). Vegetasi mangrove Gerupuk sendiri merupakan hasil rehabilitasi dan sebagian besar masih pada tipe pertumbuhan pancang atau pohon kecil. Usia vegetasi ini juga berkaitan dengan stabilitas ekosistem. Komunitas mangrove Pemongkong merupakan komunitas klimaks yang sangat stabil jika tidak ada gangguan yang cukup besar. Jika dibandingkan, komunitas mangrove Gerupuk masih berada dalam tahap inhibisi dan fasilitasi atau peremajaan sehingga belum cukup stabil (Zvonareva et al, 2015, Anwar dan Mertha, 2017; Molles dan Sher, 2019).

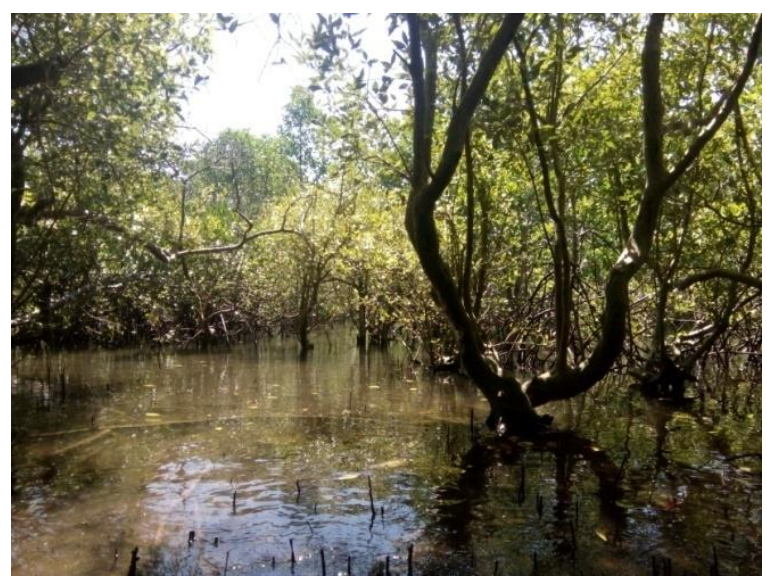

Gambar 4. Ekosistem mangrove alami Pemongkong, Lombok Timur

Tabel 2. Indeks keanekaragaman $\left(\mathrm{H}^{\prime}\right)$ dan indeks dominansi moluska asosiasi mangrove di ekosistem mangrove alami Pemongkong dan ekosistem mangrove rehabilitasi Gerupuk.

\begin{tabular}{clcc}
\hline $\begin{array}{c}\text { No } \\
\cdot\end{array}$ & Stasiun & H' & C \\
\hline 1. & Pemongkong & 3.024 & 0.062 \\
\hline 2. & Gerupuk & 2.051 & 0.167 \\
\hline
\end{tabular}

Keterangan: H' (Indeks Keanekaragaman Shannonwienner); C (indeks dominansi)

Indeks keanekaragaman (H') moluska asosiasi mangrove di ekosistem mangrove alami lebih tinggi dibandingkan dengan $\mathrm{H}^{\prime}$ moluska asosiasi di ekosistem mangrove rehabilitasi terjadi karena di kawasan mangrove alami ditemukan lebih banyak spesies moluska 
asosiasi, yaitu sekitar 34 spesies. Jumlah spesies ditemukan tersebut diikuti oleh kemelimpahan masingmasing spesies di kawasan tersebut. Selain itu, tidak terjadi dominansi moluska asosiasi jenis tertentu di kawasan terlihat dari nilai indeks dominansi (C) yang bernilai sangat kecil yaitu hanya 0,062 . Nilai indeks dominansi yang rendah menunjukkan kemerataan populasi dari masing-masing spesies moluska yang juga menunjukkan stabilitas dari ekosistem mangrove habitatnya. Nilai indeks kenanekaragaman $\left(\mathrm{H}^{\prime}\right)$ yang tinggi dan rendahnya indeks dominansi (D) dalam suatu ekosistem menunjukkan bahwa ekosistem tersebut telah cukup seimbang karena setiap spesies moluska dalam ekosistem tersebut telah memiliki relung sendiri, melakukan aktivitas biologis, dan berinteraksi tanpa gangguan yang berarti (Isnaningsih dan Patria, 2018).

Karakteristik habitat dan kondisi lingkungan seperti vegetasi, jenis sedimen, suhu, dan salinitas yang hampir sama akan memiliki komposisi jenis dan kelimpahan gastropoda yang tidak jauh berbeda pula (Pribadi et al, 2009). Pengaruh dari struktur vegetasi mangrove tersebut terletak pada ketersedian pakan bagi moluska asosiasi mangrove yang sebagian besar merupakan pemakan serasah (Sudiyasa, 2007; Budiman, 2009). Supriharyono (2009) menyatakan bahwa moluska mangrove cendrung lebih menyukai daun Avicennia marina yang tidak ditemukan di kawasan rehabilitasi mangrove Gerupuk. Selain itu, tingginya dominansi jenis Rhizophora di Gerupuk membatasi jenis-jenis moluska yang mampu berasosiasi. Moluska pemakan langsung daun mangrove memiliki sifat yang spesifik terhadap jenis-jenis mangrove tertentu (Supriharyono, 2009), sehingga jenis Rhizophora tidak dapat menggantikan jenis mangrove yang lain sebagai pakan moluska pemakan langsung daun mangrove.

Secara keseluruhan, karakter fisik dan kimia lingkungan kedua ekosistem ini tidak memilik perbedaan yang terlalu signifikan, kecuali pada parameter jenis dan kedalaman substrat. Jenis substrat di Pemongkong berkisar antara lempung hingga lumpur halus dengan kedalaman mencapai $40 \mathrm{~cm}$, sedangkan di kawasan Gerupuk, substrat berupa pasir berlumpur yang memiliki kedalaman sekitar $15 \mathrm{~cm}$. Menurut Budiman (2009), kondisi fisik dan kimia lingkungan memang dapat mempengaruhi keanekaragaman dan kemelimpahan moluska asosiasi mangrove, tetapi faktor utama pemilihan tempat hidup bagi kelompok hewan tersebut sebenarnya adalah ketersediaan pakan di suatu habitat. Ketersediaan pakan inilah yang kemudian membentuk mikrohabitat khas sehingga moluska di ekosistem dengan vegetasi mangrove serta kondisi lingkungan yang berbeda akan memiliki keanekaragaman dan kemelimpahan yang berbeda pula (Budiman, 2009).

Tingginya suhu udara dan substrat di kawasan penelitian dapat menggambarkan besarnya intensitas cahaya yang masuk ke kawasan penelitian. Hasil penelitian menunjukkan bahwa suhu substrat di kawasan penelitian berkisar antara $30-34^{\circ} \mathrm{C}$, sedangkan suhu udara sekitar $29-34{ }^{\circ} \mathrm{C}$. Dengan cahaya matahari yang masuk, berbagai jenis produsen di ekosistem mangrove dapat berkembang dengan baik dan mendorong kemelimpahan populasi moluska asosiasi mangrove seperti Neritidae, Littorinidae dan sebagainya. Intensitas cahaya matahari yang masuk dan mencapai permukaan substrat ekosistem mangrove dipengaruhi oleh kepadatan serta jenis vegetasi yang menyusun ekosistem itu sendiri. Genus Rhizophora yang banyak terdapat di ekosistem mangrove rehabiltiasi (Anwar dan Mertha, 2017; Ahyadi dan Suana, 2018) merupakan jenis tumbuhan mangrove dengan daun berukuran sedang dan kanopi yang cukup lebat sehingga cahaya yang mencapai dasar hutan menjadi kecil.

Dibandingkan dengan kondisi tersebut, ekosistem mangrove alami Pemongkong yang didominasi oleh pepohonan besar dari genus Sonneratia dan Avicennia memiliki daun yang kecil hingga sedang dengan kanopi yang tidak terlalu rapat (Noor et al, 2012; Alidrus, 2014). Intensitas cahaya yang masuk ke dasar hutan mangrove yang cukup menyebabkan alga dan fitoplankton di dasar hutan mangrove dapat tumbuh. Ketersediaan pakan itulah yang menyebabkan kemelimpahan dan keanekaragaman jenis moluska asosiasi mangrove alami Pemongkong menjadi tinggi.

\section{b. Tingkat Similaritas Kedua Ekosistem Mangrove}

Indeks similiaritas Sorensen (ISS) dan presentase similiaritas (PS) merupakan dua komponen yang digunakan untuk mengukur tingkat persamaan antara dua ekosistem yang diamati (Smith dan Smith, 2012). Indeks similiaritas Sorensen (ISS) merupakan salah satu indeks yang digunakan untuk menghitung similiaritas antara dua area atau plot sampel berdasarkan komposisi spesiesnya. Adapun PS merupakan cara menghitung tingkat kesamaan antara dua area penelitian berdasarkan proporsi kelimpahan relatif dari spesies di komunitas yang dibandingkan (Smith dan Smith, 2012). 


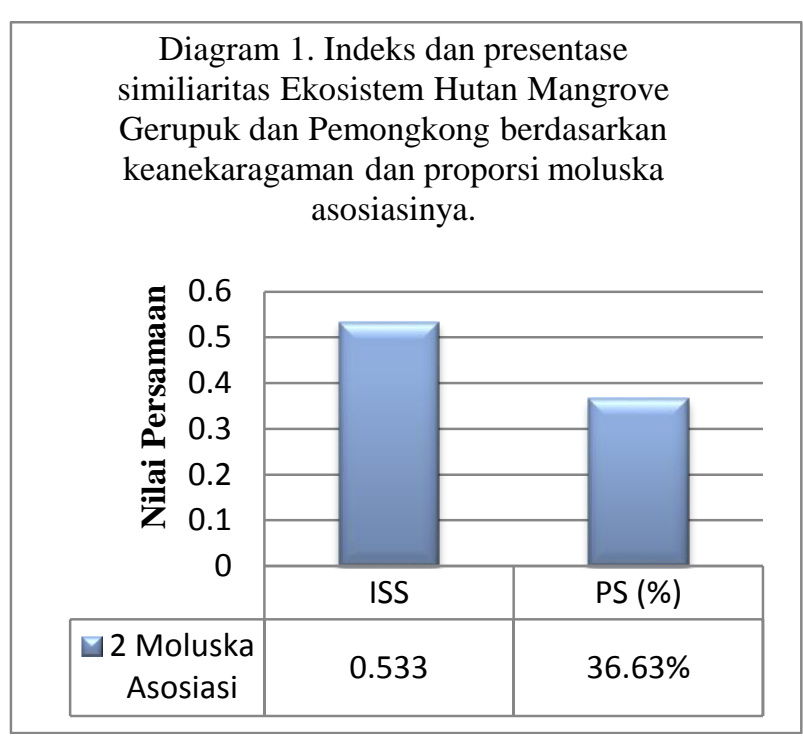

Keterangan; ISS: Indeks similiaritas Sorensen; PS: Presentase similiaritas (\%).

ISS moluska asosiasi mangrove memiliki nilai 0,533 yang termasuk ke dalam kategori sedang. Terdapat sebanyak 14 spesies moluska asosiasi mangrove yang ditemukan kedua lokasi pengamatan. Faktor yang menyebabkan nilai persamaan kedua lokasi penelitian ini termasuk ke dalam kategori sedang adalah jumlah spesies yang ditemukan adalah jenis-jenis yang ditemukan tersebut merupakan jenis moluska oportunis yang memiliki tingkat adaptasi terhadap kondisi hutan mangrove yang tinggi (Zvonareva et al, 2015). Karakter fisik dan kimia lingkungan di ekosistem mangrove Gerupuk (tabel 4.5) sudah memenuhi kriteria ekosistem yang mampu ditempati oleh moluska asosiasi oportunis sehingga 14 jenis moluska dapat ditemukan di kedua lokasi penelitian.

Akan tetapi, perbedaan yang besar antara kedua lokasi terlihat pada presentase similiaritas (PS). Moluska asosiasi mangrove memiliki PS yaitu $36.63 \%$ dan termasuk ke dalam kategori rendah. Rendahnya nilai PS tersebut menunjukkan perbedaan yang besar antara kedua lokasi penelitian dalam hal proporsi dari masingmasing spesies di dalam komunitasnya. Tinggi rendahnya jumlah individu dapat dipengaruhi oleh faktor lingkungan dan ketersediaan makanan bagi moluska. Akan tetapi menurut Budiman (2009), faktor lingkungan bukan merupakan faktor utama pemilihan tempat hidup bagi kelompok hewan, melainkan ketersediaan makanan bagi hewan tersebut. Meninjau kembali pernyataan Supriharyono (2009) mengenai moluska mangrove yang lebih menyukai serasah Avicennia spp. dibandingkan dengan Rhizophora spp., faktor pakan ini merupakan penyebab perbedaan kemelimpahan moluska di ekosistem mangrove alami dan rehabilitasi. Jenis-jenis moluska yang ditemukan di ekosistem mangrove
Gerupuk merupakan jenis yang memiliki daya adaptasi cukup baik dengan berbagai kondisi hutan mangrove. Namun jika dilihat dari jumlah spesies yang ditemukan di lokasi tersebut yaitu hanya sekitar 17 spesies, dapat dikatakan bahwa ekosistem mangrove rehabilitasi ini masih belum strabil dan berada dalam tahap transisisi (Zvonareva et al, 2015).

Kondisi fisik dan kimia lingkungan juga mempengaruhi tersedianya makanan bagi moluska. Sebagian besar moluska yang ditemukan di ekosistem mangrove alami Pemongkong merupakan pemakan alga, lumut, dan serasah daun Avicennia spp. yang tidak tersedia di ekosistem mangrove Gerupuk. Contohnya adalah famili Neritidae dan Littorinidae (Budiman, 2009; Supriharyono, 2009, Goltenboth et al, 2014). Kawasan rehabilitasi mangrove yang berada di tepian hutan mangrove Gerupuk memiliki vegetasi yang sangat lebat pada titik-titik tertentu yang tidak memungkinkan cahaya matahari masuk sehingga tumbuhan seperti alga dan lumut yang membutuhkan cahaya tidak mampu tumbuh di kawasan tersebut. Faktor ini bisa saja menjadi alasan sedikitnya spesies moluska yang didapatkan di kawasan tersebut meskipun telah berusia lebih dari 10 tahun.

\section{Kesimpulan}

Molluska merupakan salah satu kelompok fauna yang dapat digunakan sebagai bioindikator kondisi ekosistem mangrove karena spesifikasi masing-masing spesiesnya terhadap microhabitat yang ada. Berdasarkan penelitian yang telah dilakukan, ditemukan 37 spesies moluska ditemukan di kedua lokasi penelitian yang termasuk ke dalam 14 Famili (Assiminidae, Cerithidae, Ellobiidae, Himnoeidae, Littorinidae, Muricidae, Neritidae, Onchididae, Palanaxidae, Potaminidae, Trochidae, Thiaridae, Isognomonidae, dan Arcidae). Komposisi moluska asosiasi mangrove di ekosistem mangrove alami dan rehabilitasi ditunjukkan oleh tingkat keanekaragaman dan kemelimpahan moluska di kedua lokasi yang berturut-turut mencapai $77.641 \mathrm{ind} / \mathrm{m}^{2}$ dan $48.746 \mathrm{ind} / \mathrm{m}^{2}$. Tingkat similaritas kedua ekosistem tersebut tergolong rendah berdasarkan nilai persent similaritas (PS) yang diraih yaitu 36,63\%. Perbedaan tersebut menunjukkan bahwa kondisi lingkungan yang disebabkan oleh perubahan struktur vegetasi mangrove akibat rehabilitasi menyebabkan perubahan komposisi biota asosiasi mangrove yang sangat signifikan.

\section{Ucapan Terima Kasih}

Terima kasih penulis ucapkan kepada Bapak Wirya Armand dan rekan-rekan yang membantu dalam pelaksanaan penelitian, serta pihak Laboratorium Biologi Kelautan, Fakultas MIPA, Universitas Mataram. 


\section{Daftar Pustaka}

Abbott, R. T. (1991). Seashells Of South East Asia. Tyron Press. Scotland.

Abbott, R. T. \& S. P. Dance. (1998). Compendium of Sea Shells. Odyssey Publishing. USA.

Ahyadi, H., Sani. L. H., Riandinata, S. K. \& S. Hadi. (2018). The Condition of Mangrove Ecosystem Around Shipyard Project Site at Lembar Bay, Lombok. Dipresentasikan pada seminar $1^{\text {st }}$ International Conference and Workshop of Bioscience and Biotechnology, Mataram, 27 November 2018.

Ahyadi, H. \& I. W. Suana (2018). Kajian Biodiversitas Mangrove dan Burung di The Mandalika. Indonesia Tourism Development Corporation (ITDC). Lombok.

Al Idrus, Agil. (2014). Mangrove Gili Sulat Lombok Timur. Arga Puji Press. Mataram.

Anwar, H. \& Mertha, I. G. (2017). Komposisi Jenis Mangrove Di Teluk Gerupuk Kabupaten Lombok Tengah. Jurnal Sangkareang Mataram. 3 (2) p. 25-31). http://www.untb.ac.id./Juni-2017/.

Ariyanto, D., D. G. Bengen, T. Praono \& Y. Wardiatno. (2018). The Association of Cassidula nucleus (Gmelin 1971) and Cassidula angulifera (Petit 1841) with Mangrove in Banggi Coast, Central Java, Indonesia. AACL Bioflux Vol. 11 (2): 348 361. http://www.bioflux.com.ro/aaci.

Baharuddin, N., N. B. Basri \& N. H. Syawal. (2018). Marine Gastropods (Gastropoda; Mollusca) Diversity and Distribution on Intertidal Rocky Shores of Terengganu, Peninsular Malaysia. AACL Bioflux. (Vol. 11. No. 4. p. 1144 - 1155). http://www.bioflux.com.ro/aaci.

Bengen, D. G. (2003), Pedoman Teknis Pengenalan dan Pengelolaan Ekosistem Mangrove, PKSPL. IPB, Bogor.

Budiman, A. (2009), Persebaran dan Pola Kepadatan Moluska di Hutan Bakau, Berita Biologi, Vol. 9 (4), pp. 403 - 409. DOI: https://doi.org/10.14203/beritabiologi.v9i4.2011.

Ernanto, Rafki, F. Agustriani \& R. Aryawati (2010), Struktur Komunitas Gastropoda pada Ekosistem Mangrove di Muara Sungan Batang Ogan
Komering Ilir Sumatera Selatan, Maspari Journal, 1, $\quad$ pp. $\quad 73 \quad$ - 78. DOI: https://doi.org/10.36706/maspari.v1i1.1128

Fitriana, Y. R. (2006). Keanekaragaman dan Kemelimpahan Makrozoobentos di Hutan Mangrove Hasil Rehabilitasi Taman Hutan Raya Ngurah Rai Bali. Jurnal Biodiversitas. 7 (1). p. 67-72).

DOI: https://doi.org/10.13057/biodiv/d070117.

Göltenboth, Friedhelm, Kris H. Timotius, Paciencia Po Milan \& J. Margraf (2012), Ekologi Asia Tenggara: Kepulauan Indonesia, Salemba Teknika, Jakarta.

Hickman Jr, Cleveland P., L. S. Roberts, S. L. Keen, A. Larson, H. I'Anson \& D. J. Eisenhour (2008). Integrated Princples of Zoology, $14^{\text {th }}$ Edition, McGraw-Hill Companies, Inc., New York.

Indriyanto (2006). Ekologi Hutan, Bumi Aksara, Jakarta.

Jamili, S. D., Qayim I. \& Guhardja E. (2009). Struktur dan Komposisi Mangrove di Pulau Kaledupa Taman Nasional Wakatobi, Sulawesi Tenggara. Jurnal Ilmu Kelautan. (Vol. 14. p. 197-206). DOI: https://doi.org/10.14710/ik.ijms.14.4.197206.

Kordi K. \& M. Ghufran H. (2012). Ekosistem Mangrove: Potensi, Fungsi, dan Pengelolaan. PT. Rineka Cipta, Jakarta

Molles Jr., Manuel C. \& A. A. Sher. (2019). Ecology: Concepts and Applications, $8^{\text {th }}$ Edition.. McGrawHill Education. New York.

Mujiono, N. (2016), Gastropoda Marga Nerita dari Pulau Lombok. Oseana. (Vol.12. No. 3. p. 1-7). http://oseanografi.lipi.go.id/dokumen/os_xli_3_2 016.

Mujiono, N. (2016). Gastropoda Mangrove dari Pulau Lombok, Nusa Tenggara Barat. Oseanologi dan Limnologi di Indonesia. (Vol. 1. No. 3. p. 39-50). DOI: $\underline{10.14203 / \text { oldi.2016.v1i3.55 }}$

Noor, Y. R., M. Khazali \& I N. N. Suryadiputra (2012). Panduan Pengenalan Mangrove di Indonesia, Wetland International, Bogor.

Pribadi, R., R. Hartati \& C. A. Suryono (2009), Komposisi Jenis dan Distribusi Gastropoda di Kawasan Hutan Mangrove Segara Anakan 
Cilacap. Ilmu Kelautan, 14 (2), p. 102-111. DOI: https://doi.org/10.14710/ik.ijms.14.2.102-111

Smith, T. M. \& R. L. Smith (2012), Element of Ecology $8^{\text {th }}$ Edition, Pearson Education Inc., USA.

Supriharyono (2009), Konservasi Ekosistem Sumber Daya Hayati di Wilayah Pesisir dan Laut Tropis, Pustaka Pelajar, Yogyakarta.

Zvonareva, S., Y. Kantor, X. Li \& T. Britayev. (2015). Long-term Monitoring of Gastropoda (Mollusca) Fauna in Planted mangroves in Central Vietnam, In Zoological Studies: a Springer Open Journal (Vol. 54. No. 39. p. 1 - 16). DOI: https://doi.org/10.1186/s40555-015-0120-0. 